\title{
PELAKSANAAN DUKUNGAN SOSIAL OLEH BIDAN SELAMA KALA I PERSALINAN NORMAL DI RSUD dr. Hi. CHASAN BOESOIRIE TERNATE
}

\author{
Anita Vebriyanti Ohoimas ${ }^{*}$
}

\begin{abstract}
Maternal and neonatal health services is one of the elements determining the current health status. According to Word Health Organization contained $99 \%$ of maternal deaths due to labor problems or birth referred by health workers, occur in developing countries. Maternal Mortality Rate system showed a significant decrease from 1994 to 2007. The first stage of labor began his adequate and complete the cervix starts to open up $(10 \mathrm{~cm})$. Based on the results of a preliminary survey in the room obstetrics dr. Hi. Chasan Boesoirie Ternate carried through interviews and observations of HR midwives are 39 people. 50\% of midwives have training APN. This is a descriptive analytic study is to describe the implementation of social support by midwives during the first stage of normal labor in dr. Hi. Chasan Boesoirie Ternate 2013. Descriptive method is a method in researching the status of a group of people, an object, a condition, a system of thought, or even a class of events in the present. The purpose of descriptive research is to create a description, picture or painting in a systematic, factual and accurate information on the facts, the properties and the relationship between the phenomena investigated. The research was carried out in Obstetrics and Gynecology Obstetrics Space dr. Hi. Chasan Boesoirie Tenate, and a sufficient sample research within easy reach of researchers. The population in this study was a midwife who worked in the area of obstetrics dr. Hi. Chasan Boesoirie Ternate include obstetrics and dinekologi space. The number of midwives during the study as many as 38 people. The sample in this study was a midwife who helped deliver in Space Midwifery dr. Hi. Chasan Boesoirie Ternate.
\end{abstract}

Key words : Maternal, Neonatal, Cervix, dr. Hi. Chasan Boesoirie.

\section{PENDAHULUAN}

Pelayanan kesehatan maternal dan neonatal merupakan salah satu unsur penentu status kesehatan saat ini. Menurut data WHO (Word Health Organization) terdapat $99 \%$ kematian ibu akibat masalah persalinan atau kelahiran yang dirujuk oleh tenaga kesehatan, terjadi di negara-negara berkembang. Angka Kematian Ibu (AKI) secara nasional menunjukkan penurunan yang signifikan dari tahun 1994 hingga 2007. Berdasarkan Survey Demografi dan Kesehatan Indonesia (SDKI) terakhir pada tahun 2007 AKI Indonesia sebesar 228 / 100.000 kelahiran hidup, meskipun demikian angka tersebut masih tertinggi di Asia. Sementara target Rencana Pembangunan Jangka Menengah Nasional (RPJMN) ada sebesar 226/100.000 kelahiran hidup. Terlihat penurunan angka kejadian namun angka tersebut masih jauh dari Millenium Development Goals (MDGs) yang sudah harus dicapai pada tahun 2015 yaitu AKI 102/100.000 kelahiran hidup (Depkes RI, 2010).

Angka kematian ibu dan bayi merupakan tolak ukur dalam menilai derajat kesehatan suatu bangsa, oleh karena itu pemerintah sangat menekankan untuk menurunkan angka kematian ibu dan bayi melalui program-program kesehatan. Dalam pelaksanaan program kesehatan sangat dibutuhkan sumber daya manusia yang kompeten, sehingga apa yang menjadi tujuan dapat tercapai. Bidan sebagai salah satu sumber daya manusia bidang kesehatan merupakan ujung tombak atau orang yang berada di garis terdepan yang berhubungan langsung dengan wanita sebagai sasaran program. Dengan peran yang cukup besar ini maka sangat penting kiranya bagi bidan untuk senantiasa meningkatkan kompetensinya melalui pemahaman mengenai asuhan kebidanan mulai dari wanita hamil sampai nifas serta kesehatan bayi (Sulistyawati,2009). Perkembangan dalam bidang kedokteran membuktikan bahwa semua penderita sakit memiliki aspek fisik maupun psikologis, bahkan juga aspek sosial. Dalam memberikan asuhan kepada pasien, bidan harus menghargai ibu sebagai manusia secara holistik ( PP IBI, 2008 ).

Melahirkan merupakan salah satu peristiwa penting dan senantiasa diingat dalam kehidupan wanita. Setiap wanita memiliki pengalaman melahirkan tersendiri. Memori melahirkan, peristiwa dan orang-orang yang terlibat dapat bersifat negatif atau positif, dan pada akhirnya dapat menimbulkan efek emosional dan reaksi psikologis jangka pendek dan jangka panjang (Green,cit.Henderson,2008). Persalinan kala I 
dimulai sejak his adekuat dan serviks mulai membuka hingga lengkap $(10 \mathrm{~cm})$ (Depkes RI,2008). Hampir semua wanita selama kala I persalinan mengalami nyeri yang teramat sangat saat persalinan. Perawatan pendukung dan penenang selama persalinan sangat penting dalam mendukung proses persalinan karena secara signifikan dapat mengubah seluruh skenario persalinan (Sulistyawati,2009).

Dukungan langsung dalam perawatan ibu bersalin selalu penting dan menurut perawatan bidan . Kutipan kata tua dari AngloSaxon yang berarti "bersama ibu". Dukungan seperti yang digambarkan adalah langsung dan disisi ibu serta mencakup keluarga dan pendampingnya. Berdasarkan waktu yang dibutuhkan oleh setiap tahapan persalinan, kala I merupakan tahapan persalinan dengan waktu yang paling lama sehingga merupakan fase persalinan yang seharusnya banyak terjadi interaksi ibu bersalin dengan bidan sebagai penolong persalinan (Walsh,2008).

Berdasarkan hasil survey pendahuluan di ruangan kebidanan RSUD dr. H. Chasan Boesoirie Ternate yang di laksanakan melalui wawancara dan pengamatan adalah sebagai berikut : Sumber daya manusia (SDM) bidan berjumlah 39 orang dengan pendidikan D-I Kebidanan 1 orang, pendidikan D-III Kebidanan 30 orang dan pendidikan D-IV Bidan Klinik 5 orang. 2 orang berstatus kepala ruangan dan 1 orang berstatus wakil kepala ruangan dan 35 orang bidan lainnya pelaksana pelayanan penuh. $50 \%$ bidan sudah mengikuti pelatihan APN.

RSUD dr. Hi.Chasan Boesoirie Ternate adalah rumah sakit tipe B sebagai rumah sakit rujukan dan pendidikan. Dalam standar pelayanan kebidanan yaitu standar pertolongan persalinan sendiri telah disebutkan aspek dukungan sosial oleh bidan pada persalinan kala I merupakan salah satu aspek yang memegang peranan penting dalam kelancaran proses persalinan kala I. Untuk menelaah lebih lanjut melalui "Pelaksanaan Dukungan Sosial Yang Diberikan Oleh Bidan Selama Kala I Persalinan Normal di RSUD dr. Hi. Chasan Boesoirie Ternate".

\section{Rumusan Masalah}

Berdasarkan latar belakang di atas maka dapat di rumuskan masalah dalam penelitian ini adalah : "Bagaimanakah Pelaksanaan Dukungan Sosial Oleh Bidan Selama Kala I Persalinan Normal di RSUD dr. Hi.Chasan Boesoirie Ternate?".

\section{Tujuan}

\section{Tujuan Umum}

Untuk dapat mengetahui Pelaksanaan Dukungan Sosial Oleh Bidan Selama Kala I Persalinan Normal di RSUD dr. Hi.Chasan Boesoirie Ternate Tahun 2013.

\section{Tujuan Khusus}

a. Mengetahui hubungan pelaksanaan dukungan sosial oleh bidan selama kala I persalinan normal berdasarkan umur.

b. Mengetahui hubungan pelaksanaan dukungan sosial oleh bidan selama kala I persalinan normal berdasarkan tingkat pendidikan.

c. Mengetahui hubungan pelaksanaan dukungan sosial oleh bidan selama kala I persalinan normal berdasarkan masa kerja.

\section{Kerangka Konsep}

Kerangka konsep penelitian disini adalah untuk menjelaskan Gambaran Pelaksanaan Dukungan Sosial oleh Bidan Selama Kala I Persalinan Normal di RSUD dr. Hi. Chasan Boesoirie Ternate Tahun 2013.

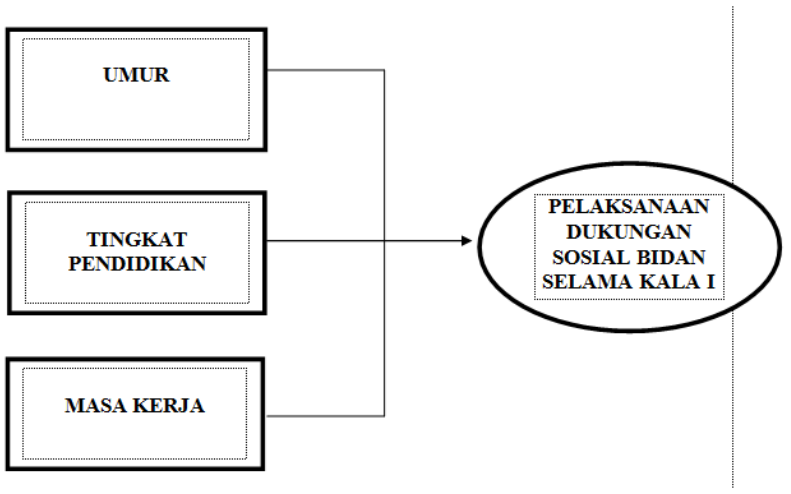

Gambar 1. Kerangka Konsep Pelaksanaan Dukungan Sosial Bidan

\section{METODE PENELITIAN}

\section{Jenis Penelitian}

Penelitian ini bersifat deskriptif analitik yaitu untuk mengetahui gambaran pelaksanaan dukungan sosial oleh bidan selama kala I persalinan normal di RSUD dr. Hi. Chasan Boesoirie Ternate Tahun 2013. Metode deskriptif adalah suatu metode dalam meneliti status sekelompok manusia, suatu objek, suatu kondisi, suatu sistem pemikiran, atau pun suatu kelas peristiwa pada masa sekarang. Tujuan dari penelitian deskriptif adalah untuk membuat deskripsi, gambaran atau lukisan secara sistematis, faktual dan akurat mengenai 
fakta - fakta, sifat - sifat serta hubungan antar fenomena yang diselidiki (Nazir, 2005).

\section{Rancangan}

Penelitian ini akan dirancang dengan menggunakan pendekatan study crosssectional, dimana data yang menyangkut suatu variabel dikumpulkan dalam waktu bersamaan (Notoatmodjo, 2005). Dalam arti kata luas, studi cross-sectional mencakup semua jenis penelitian yang pengukuran variabelvariabelnya dilakukan hanya satu kali, pada satu saat. Jadi tidak ada follow up pada studi ini (Sastroasmoro,dkk, 1995).

Gambaran Pelaksanaan Dukungan Sosial oleh Bidan

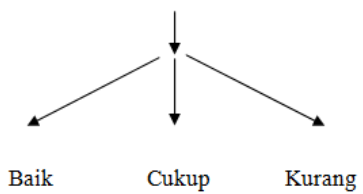

Gambar 2. Rancangan Penelitian

Secara skematis (bagan) rancangan penelitian adalah sebagai berikut : Populasi terjangkau bidan di Ruang Obstetri dan Ginekologi Kebidanan RSUD dr. Hi. Chasan Boesoirie Ternate selama kurun waktu penelitian.

\section{Lokasi dan Waktu}

Penelitian ini dilakukan di Ruang Obstetri dan Ginekologi Kebidanan RSUD dr. Hi. Chasan Boesoirie Tenate, sampel mencukupi dan tempat penelitian mudah dijangkau peneliti.

Penelitian ini dilaksanakan pada tanggal 27 November 2013 sampai dengan 17 Januari 2014.

\section{Populasi}

Populasi dalam penelitian ini adalah bidan yang bekerja di ruang kebidanan RSUD dr. Hi. Chasan Boesoirie Ternate meliputi ruang obstetri dan dinekologi. Jumlah bidan selama penelitian berlangsung sebanyak 38 orang.

\section{Sampel}

Sampel dalam penelitian ini adalah bidan yang menolong persalinan di Ruang Kebidanan RSUD dr. Hi. Chasan Boesoirie Ternate. Tehnik sampel dalam penelitian ini adalah total populasi yaitu semua bidan yang melaksanakan asuhan persalinan yang bekerja di Ruang Obstetri dan Ginekologi Rumah Sakit Umum Daerah dr. Hi. Chasan Boesoirie Ternate serta memenuhi kriteria sampel sebagai berikut :

\section{Kriteria Inklusi}

a. Bersedia menjadi responden

b. Bekerja di ruang obstetri dan ginekologi kebidanan

\section{Kriteria Eksklusi}
a. Tidak sedang dalam perjalanan dinas
b. Tidak berada di tempat tugas
c. Tidak berstatus sebagai mahasiswa izin dan tugas belajar

\section{HASIL PENELITIAN}

Pada tahap ini akan dibahas hasil penelitian yang telah diperoleh dibandingkan kajian teori sesuai variabel independen umur, tingkat pendidikan dan masa kerja dengan pelaksanaan dukungan social oleh bidan selama kala I persalinan normal di RSUD dr. H. Chasan Boesoirie Ternate tahun 2013. Dengan karakteristik Bidan diantaranya :

\section{Karakteristik Responden}

\section{Karakteristik Responden Berdasarkan Umur}

Distribusi responden berdasarkan kelompok umur dalam penelitian ini dibagi berdasarkan nilai nominal > 30 tahun dan < 30 tahun, sebagai berikut :

Tabel 1. Distribusi Freskuensi Responden Berdasarkan Umur Bidan di RSUD dr. H. Chasan Boesoirie Ternate Tahun 2013

\begin{tabular}{ccc}
\hline Umur (Tahun) & N (Jumlah) & Presentase \% \\
\hline$>30$ tahun & 25 & 64.10 \\
\hline$<30$ tahun & 14 & 35.90 \\
\hline \multicolumn{1}{c}{ Total } & & 100 \\
\hline $\begin{array}{l}\text { 2. Karakteristik Responden } \\
\text { Tingkat Pendidikan }\end{array}$ & Berdasarkan & $\begin{array}{l}\text { bagian berdasarkan skala ordinal yaitu : D- } \\
\text { I, D-III, dan D-IV. }\end{array}$
\end{tabular}

Distribusi tingkat pendidikan responden

dalam penelitian ini dibagi menjadi 3 (tiga) 
Tabel 2. Distribusi Frekuensi Responden Berdasarkan Tingkat Pendidikan Bidan di RSUD dr. H. Chasan Boesoirie Ternate Tahun 2013

\begin{tabular}{|c|c|c|}
\hline Umur (Tahun) & N (Jumlah) & Presentase \% \\
\hline $\mathrm{D}-\mathrm{I}$ & 1 & 2.56 \\
\hline D - III & 30 & 76.93 \\
\hline $\mathrm{D}-\mathrm{IV}$ & 8 & 20.51 \\
\hline \multicolumn{2}{|c|}{ TOTAL } & 100 \\
\hline
\end{tabular}

\section{Karakteristik Responden Berdasarkan}

Masa Kerja

Distribusi tingkat pendidikan responden dalam penelitian ini dibagi menjadi 3 (tiga)

bagian berdasarkan skala interval yaitu $<5$ tahun, 5-10 tahun, > 10 tahun.

Tabel 3. Distribusi Frekuensi Berdasarkan Masa Kerja Bidan di RSUD dr. H. Chasan Boesoirie Ternate Tahun 2013

\begin{tabular}{lcc}
\hline \multicolumn{1}{c}{ Umur (Tahun) } & N (Jumlah) & Presentase \% \\
\hline$>5$ tahun & 14 & 35.90 \\
\hline $5-10$ tahun & 7 & 17.95 \\
\hline$>10$ tahun & 18 & 46.15 \\
\hline Total & & 100 \\
\hline
\end{tabular}

\section{Hasil Pelaksanaan Dukungan Sosial Oleh} Bidan Selama Kala I Persalinan Normal Pelaksanaan dukungan social oleh bidan selama kala I persalinan normal diukur dari skor pada pengisian kuesioner yang sudah disediakan dengan dua criteria, yaitu 0 bila bidan menjawab tidak dalam arti pertanyaan prosedur tindakan tidak dilakukan, dan 1 bila bidan menjawab ya dalam arti pertanyaan prosedur tindakan dilakukan. Untuk mengetahui hasil pelaksanaan dukungan social oleh bidan dapat dilihat dari tabel dibawah ini :

Tabel 4. Distribusi Frekuensi Pelaksanaan Dukungan Sosial Oleh Bidan Selama Kala I Persalinan Normal di RSUD dr. H. Chasan Boesoirie Ternate Tahun 2013

\begin{tabular}{lcc}
\hline Kategori & N (Jumlah) & Presentase \% \\
\hline Baik & 34 & 87.17 \\
\hline Cukup & 5 & 12.83 \\
\hline Kurang & - & - \\
\hline Total & & 100 \\
\hline
\end{tabular}

Tabel 4. Distribusi Frekuensi Pelaksanaan Dukungan Informasional Oleh Bidan Selama Kala I Persalinan Normal di RSUD dr. H. Chasan Boesoirie Ternate Tahun 2013

\begin{tabular}{lcc}
\hline Kategori & N (Jumlah) & Presentase \% \\
\hline Baik & 25 & 64.10 \\
\hline Cukup & 14 & 35.90 \\
\hline Kurang & - & - \\
\hline Total & & $\mathbf{1 0 0}$
\end{tabular}

Tabel 5. Distribusi Frekuensi Pelaksanaan Dukungan Emosional Bidan Selama Kala I Persalinan Normal di RSUD dr. H. Chasan Boesoirie Ternate Tahun 2013

\begin{tabular}{lcc}
\hline Kategori & N (Jumlah) & Presentase \% \\
\hline Baik & 39 & 100 \\
\hline Cukup & - & - \\
\hline Kurang & - & - \\
\hline Total & & $\mathbf{1 0 0}$
\end{tabular}


Tabel 6. Distribusi Frekuensi Pelaksanaan Dukungan Penghargaan Bidan Selama Kala I Persalinan Normal di RSUD dr. H. Chasan Boesoirie Ternate Tahun 2013

\begin{tabular}{lcc}
\hline Kategori & N (Jumlah) & Presentase \% \\
\hline Baik & 39 & \\
\hline Cukup & - & 100 \\
\hline Kurang & - & - \\
\hline Total & & 100 \\
\hline
\end{tabular}

Tabel 7. Distribusi Frekuensi Pelaksanaan Dukungan Instrumen / Fisik Oleh Bidan Selama Kala I Persalinan Normal di RSUD dr. H. Chasan Boesoirie Ternate Tahun 2013

\begin{tabular}{lcc}
\hline Kategori & N (Jumlah) & Presentase \% \\
\hline Baik & & \\
\hline Cukup & 24 & 61.55 \\
\hline Kurang & 11 & 28.20 \\
\hline Total & 4 & 10.25 \\
\hline
\end{tabular}

\section{PEMBAHASAN}

Penelitian ini bertujuan untuk mengetahui gambaran pelaksanaan dukungan sosial oleh bidan selama kala I persalinan normal di RSUD dr. H. Chasan Boesoirie Ternate. Penelitian ini dilaksanakan sejak tangga 19 sampai dengan 22 Desember 2013. Sampel penelitian ini sebanayak 39 responden bidan dengan menjawab pertanyaan yang diberikan pada kuesioner. Penelitian ini dilakukan secara deskriptif analitik dengan uji univariat dan bivariat.

\section{Analisis Univariat}

\section{Karakteristik berdasarkan Umur Responden}

Analisis univariat atau deskriptif dari variabel penelitian adalah untuk memberikan gambaran distribusi frekuensi berdasarkan variabel waktu tempat dan orang, penyajian data di lakukan dalam bentuk tabel distribusi frekuensi dan narasi. Selanjutnya untuk golongan umur responden pada tabel satu menunjukan distribusi responden berdasarkan golongan umur bidan tentang penata laksanaan dukungan sosial bidan dalam kala I pesalinan normal yang terbanyak adalah golongan umur $>30$ tahun yaitu 25 orang $(64,1 \%)$ disusul golongan umur $<30$ tahun $(35,9 \%)$. Dengan bertambahnya umur seorang akan terjadi perubahan pada aspek fisik dan psikologi (mental), perubahan tersebut tidak hanya terjadi pada perubahan ciri fisik seseorang akan tetapi terjadi pula pada psikologi atau mental.

Hasil penelitian ini sama halnya dengan penelitian rahastari (2008) dan misnawati (2010) dalam hasil penelitiannya mengatakan bahwa usia tua maupun muda tidak ada perbedaan yang signifikan dalam dalam memberikan dukungan sosial pada kala I persalinan.

2. Karakteristik Berdasarkan Tingkat Pendidikan Responden

Tingkat pendidikan terlihat bahwa distribusi responden berdasarkan tingkat pendidikan bidan tentang penatalaksanaan dukungan sosial oleh bidan dalam kala I persalinana normal di RSUD dr. H. Chasan Boesoirie Ternate yang paling banyak adalah kategori tingkat pendidikan D-III kebidanana adalah sebanyak 30 orang (76,9\%), D-IV sebanyak 8 orang $(20,5 \%)$ dan D-I yaitu 1 orang $(2,6 \%)$.

Hal tersebut sejalan dengan hasil penelitian Rahastari (2008) yang mengemukakakn bahwa pendidikan berhubungan dengan pengetahuan dan keterampilan dalam penatalaksanaan dukungan sosial oleh bidan dalam kala I asuhan perasalinana normal, makin tinggi tingkat pendidikan seorang maka akan terjadi kecendrungan seorang bidan dalam memberikan pelayanan kesehatan secara baik dan profesional hal tersebut sejalan dengan penelitian minawati (2010). 


\section{Karakteristik Berdasarkan Masa Kerja Responden}

Hasil penelitian menunjukan bahwa masa kerja bidan bervariasi $>10$ tahun $(46,2 \%)$ sebanyak $18 \mathrm{n}$ orang, $<5$ tahun $(35,9 \%)$ sebanyak 14 orang, dan 5-10 tahun (17,9\%) adalah 7 orang. Hal ini menunjukan bahwa bidan di RSUD dr. H. Chasan Boesoirie Ternate lebih banyak bidan dengan pengalaman kerja yang lebih lama sehingga di harapkan semakin banyak pengalaman maka semakin baik kemampuan kerja seorang tenaga kerja Notoatmojo (2003). Hasil penelitian ini sama halnya dengan hasil penelitian rahastari (2008) bahwa sebagian besar bidan di RSUD Wonosari Yogyakarta dan Hasil penelitian Misnawati (2010) di RSUD dr. H. Chasan Boesoirie Ternate 2013, di dominasi oleh bidan dengan masa kerja > 10 tahun.

\section{Analisis Bivariat}

1. Hubungan Pelaksanaan Dukungan Sosial Oleh Bidan Selama Kala I Persalinana Normal Dengan Umur RSUD dr. $H$. Chasan Boesoirie Ternate Tahun 2013

Hubungan bidan dengan penata laksananaan dukungan sosial selama kala 1 persalinana normal di ruang kebidanana RSUD dr. H. Chasan Boesoirie Ternate, responden lebih banyak adalah kelompok bidan dengan umur $>30$ Tahun sebanyak 25 orang $(64,1 \%)$.

Hubungan berdasarkan umur bidan tentang penata laksanaan dukungan sosial selama kala I persalinan normal secara statistik tidak bermakna dengan $\mathrm{CI}=433$ tingkat signifikan $95 \%$.

Hal ini sejalan dengan hasil penelitian Misnawati (2010), yang mana faktor umur dari kedua kategori terlihat tidak memberikan dukungan instrumen / fisik dan dukungan innformasional.

2. Hubungan Pelaksanaan Dukungan Sosial Oleh Bidan Selama Kala I Persalinana Normal Dengan Masa Kerja RSUD dr. H. Chasan Boesoirie Ternate Tahun 2013

Sebagaian besar responden yang masuk kedalama kategori lamanya kerja anatara > 10 tahun $(46,2 \%)$ dan selanjutnya disusun bidan dengan lamanya kerja $<5$ tahun yaitu 15 responden $(35,5 \%)$ dan kategori mas kerja yang paling sedikit adalah 5-10 tahun sebanyak 7 responden $(17,9 \%)$.

Namun demikian responden yan memeiliki masa kerja > 10 tahun mempunyai peluang
50\% untuk melakukan penata laksanaan dukungan sosial selama kala I persalinan normal, dibandingkan dengan yang $<10$ tahun masa kerja karena hasil analisis menunjukan sangat berhubungan / bermakna secara statistik dengan nilai $\mathrm{CI}=721$.

Hal ini sejalan dengan penelitian rahastari (2008), dan Misnawati (2010) menyatakan semakin lama masa kerja bidan maka semakin banyak pengalaman yang dimiliki dalam memberikan palayanan dibandingkan dengan bidan yang baru bekerja.

3. Hubungan Pelaksanaan Dukungan Sosial Oleh Bidan Selama Kala I Persalinana Normal Dengan Tingkat Pendidikan di RSUD dr. H. Chasan Boesoirie Ternate Tahun 2013

Tingkat pengetahuan bidan dalam penata laksanaan dukungan sosial selama kala I persalinan normal menunjukan hubungan yang signifikan / bermakna secara statistik antara bidan yang mempunyai tingkat pendidikan tinggi maupun bidan yang memiliki pengetahuan kurang dengan nilai $\mathrm{P}=$ Value 0,30 pada tingkat signifikansi 95\%. Dengan kata lain dapat dinyatakan bahawa bidan dengan tingkat pendidikan kurang mempunyai faktor resiko protektif terhadap tindakan yang dilakukan.

Penelitian ini juga sejalan dengan penelitian yang dilakukan oleh Rahastari (2008) dan Misnawati (2010) dimana tingkat pendidikan bidan sangat berpengaruh terhadaop kemampuan dan keterampilan dalam melakukan perencanaan asuhan persalinana normal.

\section{KESIMPULAN DAN SARAN}

\section{Kesimpulan}

1. Dukungan sosial yang dilakukan mayoritas oleh bidan adalah baik $(87,17 \%)$, namun angka ini menurun dari hasil penelitian misnawati 2010 yaitu $(89,47 \%)$.

2. Pelaksanaan dukungan sosial secara keseluruhan oleh bidan selama kala I persalinan normal adalah baik, hanya pada dukungan instrumen / fisik presentasi cukup $28,20 \%$ kurang $10,25 \%$ darai angka baik $61,55 \%$, sementara dukungan informasi presentasi ci=ukup 35, 90\% dari anngka 64, $10 \%$. Sehingga terlihat kedua dukungan ini penatalakasana baru terlaksana $65 \%$ yang tidak didominasi oleh masing-masing karakteristik. 


\section{Saran}

1. Dukungan sosial tidak akan berjalan dengan baik bila hanya dilaksanakan oleh bidan. Peran ibu bersalin suami dan keluarga terdekat akan mengoptimalkan jalannya dukungan sosial selama kala I persalinana normal.

2. Penata laksanaan dukunan sosial oleh bidan kiranya dapat di sosialisasikan kepada semua bidan yang bertugas bila dapat di buat dalam bentuk protab secara tertulis.

\section{DAFTAR PUSTAKA}

Abdillah P, 2006, Kamus Ilmiah Populer Lengkap, Edisi Smart, Surabaya : Arkola.

Arikunto, S, 2006. Prosedur Penelitian Suatu Pendekatan Praktek. Rineka Cipta Yogjakarta

Azwar, A, 1996, Pengantar Administrasi Kesehatan, Edisi ketiga, Jakarta : Rineka Cipta.

Budiarto E, 2002, Biostatistik Untuk Kedokteran dan Kesehatan Masyarakat, EGC Jakarta

Depkes, JNPK-KR, IHPIGO, PRIME, 1999, Buku Acuan Persalinan Dasar, Jakarta : Depkes RI

Depkes RI, 2008, Asuhan Persalinan Normal, Jakarta : Depkes RI, 2000, Standar Pelayanan Kebidanan, Jakarta : Depkes RI

Dinas Kesehatan, 2013, Profil Kesehatan Propinsi Maluku Utara, 2013, Profil Kesehatan Kota Ternate

Hakimi, 2003, Fisiologi dan Patologi Persalinan, Jakarta, Yayasan Essentia Medica

Hany, 2002, Buku Saku Bidan, Jakarta, EGC.

Henderson, 2006, Buku Ajar Konsep Kebidanan, Jakarta, EGC

Kuncara, 2006, Asuhan Kebidanan Selama Persalinan dan Kelahiran, Jakarta, EGC

Mangesthi Rahastari, 2008, Penelitian dengan Judul Gambaran Pelaksanaan Dukungan Sosial Oleh Bidan Selama Kala I Persalinan Normal di RSUD Wonosari, Yogyakarta.

Nazir M, 2005, Metode Penelitian, Jakarta : Ghalia Indonesia

Notoatmodjo, S. 2002, Metodologi Penelitian Kesehatan, Cetakan ke -2 Rineka Cipta Jakarta., 2002, Metodologi Penelitian Kesehatan, Rineka Cipta, Jakarta
Prawirohardjo Sarwono, 2007, Ilmu Kebidanan, Yayasan Bina Pustaka Sarwono Prawirihardjo, Jakarta

PP IBI, 2008, 50 Tahun Ikatan Bidan Indonesia, Bidan Menyongsong Masa Depan, Jakarta : PP IBI

Medical Record, 2013, Data RSUD dr. Hi. Chasan Boesoirie Ternate

Sulistyawati, 2009, Asuhan Kebidanan Pada Masa Kehamilan, Jakarta : Salemba Medika

Sumarah dkk, 2009, Perawatan Ibu Bersalin, Yogyakarta : Fitramaya

Sugiyono, 2008, Statistika Untuk Penelitian, Jakarta : Alfabeta

Saryono, 2009, Metodologi Penelitian Kesehatan, Yogyakarta : Mitra Cendikia

Sastroasmoro, 1995, Dasar-Dasar Metodologi Penelitian Klinis, Jakarta : Universitas Indonesia

Saifuddin, 2006, Buku Acuan Nasional Pelayanan Kesehatan Maternal dan Neonatal, Jakarta : Yayasan Bina Pustaka Sarwono Prawirohardjo

Subekti, 2003, Perawatan dalam Kelahiran Normal, Jakarta, EGC

Uripni dkk, 2008, Komunikasi Kebidanan, Jakarta, EGC

Wiknjosastro, 2006, Ilmu Kebidanan, Jakarta, Yayasan Bina Pustaka Prawirohardjo

Walsh V. Linda, 2008, Buku Ajar Kebidanan Komunitas, Jakarta, EGC. 
